\title{
Clinical characteristics and determinants of glycaemic control among type 2 diabetes mellitus (T2DM) patients in Fiji
}

\section{Pablo Romakin}

Fiji National University College of Medicine Nursing and Health Sciences

\section{Donald Wilson}

Fiji National University College of Medicine Nursing and Health Sciences

\section{Sabiha Khan}

Fiji National University College of Medicine Nursing and Health Sciences

Masoud Mohaammadnezhad ( $\nabla$ masraqo@hotmail.com )

Fiji National University https://orcid.org/0000-0002-5048-9719

\section{Research}

Keywords: Clinical Characteristics, Determinants, Glycaemic Control, Type 2 Diabetes Mellitus, Fiji

Posted Date: January 18th, 2021

DOI: https://doi.org/10.21203/rs.3.rs-47923/v2

License: (a) (i) This work is licensed under a Creative Commons Attribution 4.0 International License. Read Full License 


\section{Abstract}

Background: Glycemic control is the centre in diabetes management. In patients with type 2 diabetes mellitus (T2DM), glycemic control is associated with clinical determinants. The aim of this study was to determine the proportion of poor glycemic control level and its clinical determinants among T2DM patients.

Methods: This retrospective cross-sectional study was conducted on the medical records of T2DM patients attending diabetes clinics at the three selected health centres in Suva, Fiji. Patients who met the following criteria were included in the study: adult T2DM $\geq 18$ years old registered during 2011 to 2016; on treatment for >1year; had $>4$ clinic visits and; had a recent $\mathrm{HbA1c}$ result in 2017. Logistic regression analysis was performed. A $p$ value of $<0.05$ was considered as significant.

Results: There were 200 female (59.2\%) and 138 male (40.8\%) T2DM patients included in this study with a mean age of 56.5 years $(S D= \pm 9.9)$. Majority have poorly controlled random blood sugar $(\mathrm{RBS}), 67.1 \%$ and fasting blood sugar (FBS), 63.0\%. Two-thirds (65.4\%) had co-morbidities. The proportion of poor glycaemic control $(\mathrm{HbA} 1 \mathrm{c}<7 \%)$ was $77.2 \%$ with mean $\mathrm{HbA} 1 \mathrm{c}$ of $8.6 \%$ ( \pm 2.04$)$. RBS, FBS, cholesterol, estimated glomerular filtration rate (eGFR) and diastolic blood pressure (DBP) were significant $(p<0.05)$ determinants of poor glycaemic control.

Conclusions: This study identified clinical determinants of T2DM patients that are highly associated with glycemic control. Health care workers managing T2DM patients should address these clinical determinants in order to achieve glycemic control.

\section{Background}

Diabetes is a global health problem reaching pandemic proportions that disables and kills people, striking them at their most productive age [1,2]. The International Diabetes Federation (IDF) estimated that 424.9 million people or $8.8 \%$ of people 20 - 79 years are suffering from diabetes globally in 2017 and predicted to rise to 628.6 million in 2045 if the trends continue. Diabetes affects 1 in 11 people where 1 in 2 adults is undiagnosed; and $12 \%$ of global health expenditure (USD 727 billion) which corresponds to one for every eight dollars spent on health care [1]. It is the second leading cause of years of life lost to premature deaths and fourth leading cause of years lived with disability [3].

T2DM which constitute about $90 \%$ of all diabetes is defined as a chronic medical condition that occurs when the body cannot produce enough insulin or cannot use insulin in adults. A diagnosis of T2DM is made when a fasting blood sugar (FBS) level is $>7.0 \mathrm{mmol} / \mathrm{L}$ or $\mathrm{HbA} 1 \mathrm{c}$ of $>6.5 \%$ [4-7]. The centre of diabetes management is to maintain good glycemic control $(\mathrm{HbA} 1 \mathrm{c}<7 \%)$ in order to prevent or delay onset of complications [6,7]. The United Kingdom Prospective Diabetes Study (UKPDS) has shown that each $1 \%$ reduction in mean $\mathrm{HbA} 1 \mathrm{c}$ in T2DM patients was associated with reductions in risk of diabetes related deaths by $21 \%$, stroke by $12 \%$, myocardial infarction by $14 \%$, heart failure by $16 \%$, microvascular end point by $37 \%$ and amputation from peripheral vascular disease by $40 \%$ [8]. 
The small island states of the Pacific Island Countries and Territories (PICTs) have high prevalence rates of diabetes, where over $70 \%$ of T2DM patients have poor glycemic control [9]. This has been attributed to high rates of obesity and changes in lifestyle factors due rapid industrialization and urbanization in the region [9-11].

In Fiji, diabetes has a prevalence rate of $15.6 \%$ in 2011 which is estimated to rise to $19.3 \%$ in 2020 due to rising obesity trends $[12,13]$. Diabetes is also the number one cause of disease specific mortality, most premature death and health problem causing the most disability in 2005 to 2016 [14]. In 2015, it caused $19.7 \%$ of all deaths with a mortality rate of 151.8 per 1,000 population and hospital admission rate of 134.5 per 1,000 admissions due to complications [15].

Many research studies, both quantitative and qualitative, have been conducted to determine the various factors associated with glycemic control among T2DM patients. These factors have been classified into patient-related factors, factors related to the health care team and health system factors. Among the patient-related factors associated with glycaemic control include socio-demographic characteristics such as age, gender, ethnicity and educational background; clinical characteristics; associated medical condition; treatment and treatment adherence; self-management practices and diabetes clinic attendance $[16,17]$. Research studies show that patient clinical characteristics are highly associated with glycaemic control. These include duration of diabetes, body mass index (BMI), blood pressure, random blood sugar (RBS), fasting blood sugar (FBS), total cholesterol, triglyceride, renal functions as measured by estimated glomerular filtration rate (eGFR) and the presence of associated medical conditions or co-morbidities [1824].

There have been no current published and peer reviewed studies conducted in Fiji to determine the clinical determinants of T2DM and their association with glycaemic control. Hence, the aim of this retrospective study was to determine the proportion of poor glycaemic control level among adult T2DM adult patients attending clinics at the three selected Suva health centres in 2011 - 2016, the clinical characteristics and determinants that are associated with it.

The findings of this study will be beneficial to the Fiji Ministry of Health and Medical services by providing information on the current proportion of poor glycaemic control among T2DM patients that will assist in planning and prioritizing its resources to ensure that those patients with poor glycaemic control are identified and appropriate services provided.

\section{Methods}

This cross-sectional research study was conducted using a five-year retrospective medical records audit of randomly selected T2DM patients attending diabetes clinics at three selected urban health centres in Suva, Fiji between the period August 1, 2011 and August 1, 2016.. The three selected health centres were Lami Health Centre, Suva Diabetes Centre and Valelevu Health Centre with a total of 992, 563, and 518 registered T2DM patients during this period. The following inclusion criteria were used in this study: adult T2DM 18 years old and over; on diabetes treatment for more than one year; has been attending clinic for 
4 or more occasions and; had a recent $\mathrm{HbA} 1$ test result in 2017. Those that did not meet the above inclusion criteria, Type 1 diabetes patients and those with incomplete records were excluded from this study.

A sample size of 354 was calculated using a proportionate sampling method: $5 \%$ margin of error and $95 \%$ confidence interval $(\mathrm{Cl})$ using $32.2 \%$ proportion of poor glycaemic control [25] and adjusted by a factor of $10 \%$ for incomplete medical records. A systematic random sampling method was used to select T2DM patient records where every third $\left(3^{\text {rd }}\right)$ folder were chosen from the diabetes register of the selected health centres. Three hundred thirty-eight (338) records met the inclusion criteria out of the 354 calculated samples with a response rate of $95 \%$.

Glycemic control was the dependent variable in this study. HbA1c $\geq 7 \%$ defines poor glycemic control, while $\mathrm{HbA} 1 \mathrm{c}<7 \%$ constitute good glycemic control [4-7]. The patient's most recent $\mathrm{HbA} 1 \mathrm{c}$ test result in 2017 was used as a measure of glycemic control [26,27]. Duration of diabetes, BMI, RBS, FBS, systolic blood pressure (SBP), diastolic blood pressure (DBP), cholesterol, triglyceride, eGFR and co-morbidities were the independent variables used in this study.

Data analysis used International Business Machine (IBM) Statistical Package for Social Sciences (SPSS) version 22.0 software. Descriptive statistics were used to describe the data using mean, standard deviation, frequency and percentage as well as to determine the glycemic control level among T2DM patients. Logistic regression analyses were performed to assess the effect of patient's clinical characteristics on glycemic control. $\mathrm{P}$ values $<.05$ were considered significant. Further analysis was done using forward logistic regression to test the likelihood ratio (chi square difference), starting with the constant-only model and adding variables one at a time. All the factors that were significant were ultimately introduced in the final model where statistical variables with $p<0.05$ were accepted.

\section{Results}

Data were collated from 338 T2DM patient's clinical records out of 354 that were considered eligible for this study. Sixteen records were excluded due to incomplete information. The T2DM patients in this study were composed of 200 females $(59.2 \%)$ and 138 males (40.8\%). The mean age was 56.5 years $(S D= \pm$ 9.9) and ranged from $30-82$ years. Fig. 1 shows patient selection flowchart.

\section{Glycemic control of T2DM participants}

The proportion of poor glycemic control ( $\mathrm{HbA} 1 \mathrm{c} \geq 7.0 \%)$ in this study was $77.2 \%$ while only $22.8 \%$ achieved good glycemic targets ( $\mathrm{HbA} 1 \mathrm{c}<7.0 \%)$. The mean $\mathrm{HbA} 1 \mathrm{c}$ was $8.6 \%(S D= \pm 2.4)$ with a range of $5.0 \%-16.6 \%$.

\section{Clinical characteristics of T2DM participants}


More than half $(61.5 \%)$ of the T2DM patients had the disease for less than 5 years with majority of them were overweight (42.9\%) and obese (38.8\%). Most of T2DM patients have poorly controlled RBS (67.1\%), FBS (63.0\%) and total blood cholesterol (44.1\%). About two-thirds $(65.4 \%)$ of the T2DM patients have comorbidities "Table 1".

\section{Association of T2DM clinical characteristics on glycemic control}

Bivariate analysis was conducted on each of the T2DM patient's clinical characteristics separately to look for any significant association with poor glycemic control. Bivariate analysis showed that there were significantly higher chances of poor glycemic control among T2DM patients with fairly and poorly controlled RBS, poorly controlled FBS and poorly controlled cholesterol compared to good control of these clinical determinants. Those with fairly and poorly controlled eGFR have significantly lesser chances of having poor glycemic control. These determinants were significant at $p<.05$ "Table 2 ".

\section{Logistic regression analysis}

Logistics regression analysis was done on T2DM clinical characteristics to eliminate confounding effect as there are more than one independent variables. RBS, FBS, DBP, cholesterol and eGFR were significant factors that influenced poor glycaemic control "Table 3 ".

Further analysis used stepwise logistic regression where all variables with $p>.05$ were excluded. Variables with $p<.05$ were accepted in the final model. RBS, FBS, Cholesterol, eGFR and DBP variables remained in the final model "Table 4 ".

The final logistic regression model was statistically significant, indicating that the clinical determinants as a set reliably distinguished between poor and good glycemic control $\left(X^{2}=127.15, p<.001, d f=19\right)$. The model explained $47.6 \%$ (Nagelkerke $R^{2}$ ) of the variance in those with poor glycemic control and correctly classified $84.6 \%$ of the cases. The chances of T2DM patients with fairly controlled RBS were 9 times and those with poorly controlled RBS were 7 times more likely to have poor glycaemic control compared to those with normal RBS. T2DM patients with poorly controlled FBS and cholesterol were 10 and 4 times, respectively, more chances of having poor glycemic that those with good control of these clinical determinants. However, T2DM patients with poorly controlled DBP, fairly and poorly controlled eGFR had $68 \%, 80 \%$ and $67 \%$ less chances of having poor glycaemic control than those with good control, respectively "Table 4 ". The predicted probability was $87.8 \%$ (Receiver operating characteristics (ROC) curve).

\section{Discussion}

This study sought to identify the clinical characteristics and determinants of glycemic control among T2DM patients attending clinics at the three selected health centres in Suva, Fiji in $2011-2016$ using a 5 -year retrospective folder audit. The results of this study showed a mean $\mathrm{HbA1c}$ of $8.6 \%(S D= \pm 2.04)$ which was higher compared to the result of the study conducted by Brian et al among 1,131 T2DM 
patients in Fiji as part of the HbA1c data collected during the Fiji Eye Health Survey 2009 (mean HbA1c = $6.5 \%, S D= \pm 1.3)[28]$. The proportion of poor glycaemic control $(\mathrm{HbA1c} \geq 7 \%)$ in this study was $77.2 \%$ which is similar to the results of the previous studies done in Fiji in 2014 by Kumar et al [29] and those conducted in low and middle income countries [29-32]. Despite stringent glycemic control to prevent complications, generally over $60 \%$ of T2DM patients do not achieve the recommended glycemic targets $(\mathrm{HbA} 1 \mathrm{c}<7 \%)[33]$.

Using logistic regression analysis, this study found that RBS, FBS, cholesterol, eGFR and DBP as significant determinants of poor glycemic control. The chances of T2DM patients with fairly controlled RBS were 9 times and those with poorly controlled RBS were 7 times more likely to have poor glycaemic control compared to those with normal RBS. This is similar to the results of the studies conducted by Kazmi et al on 106 randomly selected T2DM patients and by Rasmussen et al on 78 T2DM patients where they found a significant linear positive correlation between RBS and HbA1c level, $p<.01$ and < .001 , respectively [34,35]. Also, another study conducted by Sacks among 300 T2DM patients found a good correlation between $\mathrm{HbA} 1 \mathrm{c}$ and average blood random blood glucose levels and suggested to derive a regression equation that permits conversion of $\mathrm{HbA} 1 \mathrm{c}$ results into estimated average random blood glucose values [36]. This significant association of RBS with glycaemic control highlights the importance of this simple and cost-effective test which can be used by patients in self-blood sugar monitoring and by primary care diabetes clinics in targeted HbA1c testing. However, Rohlfing et al on their study on defining the relationship between plasma glucose and HbA1c: analysis of glucose profiles and $\mathrm{HbA} 1 \mathrm{c}$ in the diabetes control and complications trial (DCCT) suggest with caution that short term RBS can fluctuate markedly which may result in significant discrepancies when attempting to estimate $\mathrm{HbA1c}$ [37].

This study also found that T2DM patients with poorly controlled FBS were 10 times more chances of having poor glycaemic control than those with good FBS control. This is similar to the studies conducted by Mahato et al among 294 T2DM patients in Nepal [38]. However, some studies show that FBS provides a short-term picture of glycaemic control and only moderately correlates with hyperglycemia and poorly predicts and may underestimate $\mathrm{HbA} 1 \mathrm{c}$ at higher glucose levels [37, 39]. It is necessary to have a clear understanding of the relationship between RBS and $\mathrm{HbA1c}$ as well as FBS and $\mathrm{HbA} 1 \mathrm{c}$ for both T2DM patients and their health care providers which may be used in adjusting management interventions based on regular RBS and FBS monitoring with the expectation of achieving glycaemic control rather than relying solely on $\mathrm{HbA} 1 \mathrm{c}$ testing especially in resource-constrained settings like Fiji where $\mathrm{HbA} 1 \mathrm{c}$ testing is not always available.

Total cholesterol in this study was found to be significantly correlated with poor glycaemic control where T2DM patients with poorly controlled cholesterol level were 4 times higher chances of having poor glycemic control compared to those with good control. This is similar to the findings of other studies that higher total cholesterol concentration is an independent predictor of poor glycaemic control $[38,40]$. T2DM is characterized by hyperglycemia, insulin deficiency and insulin resistance which contribute to the abnormal lipid profile or dyslipidemia [41]. Dyslipidemia is a very important factor in T2DM patients since 
controlling it may not only indirectly result to better glycaemic control but may also result to reduced cardiovascular events.

This study found that T2DM patients with fairly and poorly controlled eGFR had $80 \%$ and $67 \%$ less chances, respectively, of having poor glycaemic control than those with good control [42]. The reason for this is unclear but could be related to the use of insulin as the main treatment regimen in patients with reduced renal function due to increased insulin resistance and abnormalities in glucose metabolism [43]. Studies however, found that low eGFR is an independent factor with poor glycemic control white other studies found no significant association with eGFR and glycemic control [44]. Diastolic pressure has negative correlation with poor glycaemic control in this study where those T2DM patients with poorly controlled DPB have $68 \%$ less chances of having poor glycemic control. There is no definite reason for this but some studies found that patients receiving antihypertensive treatment, regardless of whether BP was controlled or not, were more likely to have optimal $\mathrm{HbA1c}$ control compared with participants without hypertension $[45,46]$. Most studies however found a strong positive association with DBP where tight blood pressure control reduces risk of diabetes complications $(p<.001)[47,48]$.

This study has its limitations. It only considered patient's clinical characteristics associated with poor glycaemic control. Other factors such as the T2DM patient's socio-demographic and treatment characteristics need to be considered to shed more light on other important predictors and determinants of poor glycemic control.

\section{Conclusions}

The results of this study showed a high proportion of T2DM patients with poor glycemic control (77.2\%). The chances of T2DM patients with fairly controlled RBS were 9 times and those with poorly controlled RBS were 7 times more likely to have poor glycemic control compared to those with normal RBS. T2DM patients with poorly controlled FBS and cholesterol were 10 and 4 times, respectively, more chances of having poor glycemic that those with good control of these clinical determinants. However, T2DM patients with poorly controlled DBP, fairly and poorly controlled eGFR had $68 \%, 80 \%$ and $67 \%$ less chances of having poor glycemic control than those with good control, respectively.

This study recommends that health care workers managing T2DM patients should address their clinical determinants in order to achieve glycemic control. Due to its positive correlation with glycemic control, regular RBS testing is recommended to monitor glycemic control with targeted $\mathrm{HbA} 1 \mathrm{c}$ testing in resourcelimited settings where $\mathrm{HbA} 1 \mathrm{c}$ testing is not always available. Further studies are needed to determine the clinical determinants of poor glycemic control among T2DM patients.

\section{Declarations}

\section{Ethics approval and consent to participate}


Ethics approval were obtained from the Fiji National University College Health Research Ethics Committee (CHREC) and the Fiji National Health Research Ethics and Review Committee (FNHRECRC). Written approvals were also obtained from the medical officers' in-charge of the selected health facilities as well as from the Permanent Secretary for Health and Medical Services to collect data from the patient's folders before commencing the study. T2DM patient's folders were de-identified before accessing data to ensure confidentiality. The patient's informed consent to access their medical records were waived by the FNHRERC as per Fiji's medical records policy.

\section{Consent for publication}

Not applicable.

\section{Availability of data and materials}

All authors declare that data and any supporting material regarding this manuscript are available and can be requested at any time.

\section{Competing Interest}

The authors declare they have no competing interest.

Funding: This research received no specific grant from any funding agency in the public, commercial or not-for-profit sectors.

Author Contributions: Research proposal was written by P.R. and was guided by other authors. The data was collected and analysed by AR and revised by other authors. All authors were involved in the final version of the manuscript. All authors have read and agreed to the published version of the manuscript.

Acknowledgments: The authors would like to acknowledge Ministry of Health and Medical Services Fiji for giving approval to access T2DM patient's medical records and the diabetes clinic staff of the selected health centres for their support during data collection.

\section{References}

1. International Diabetes Federation Eighth edition. IDF Diabetes Atlas. 2017 [cited 2017 Dec 11]; 40 -58. Available from: http:/www.diabetesatlas.org

2. The Lancet. The diabetes pandemic. 2011; 378 (9786): 99. Available from: DOI: https://doi.org/10.1016/S0140-6736(11)61068-4

3. World Health Organization. Global health risks: mortality and burden of disease attributable to selected major risks. 2009. Available from http:// www.who.int/healthinfo/global_burden_ disease/GlobalHealthRisks_ report

4. American Diabetes Association. Standards of medical care in diabetes - 2017. Diabetes care. 2017; 35 (1): 520. Available from: http://care.diabetesjournals.org/content/diacare/35/ supplement- 
1/S11.full.pdf

5. Ministry of Health Government of Fiji. Diabetes management guidelines 3rd ed. 2012.

6. World Health Organization. Definition and diagnosis of diabetes mellitus and intermediate hyperglycaemia report of WHO/IDF consultation. 2006; 7. Available from: http://www. who.int

7. International Diabetes Federation. Recommendations for managing type 2 diabetes in primary care. International Diabetes Federation. 2017; Available from: https://www.idf.org/managing-type2diabetes

8. Stratton IM, Adler Al, Neil HAW, Matthews DR, Manley SE, Cull CA, et al. Association of glycaemia with macrovascular and microvascular complications of type 2 diabetes (UKPDS 35): prospective observational study. BMJ. 2000; 321: 405-12. Available from: http://www.bmj.com/content/321/ $7258 / 405$

9. Tin ST, Lee CM, Colagiuri R. A profile of diabetes in Pacific Island Countries and Territories. Diabetes Res Clin Pract. 2015; 107 (2): 233-46 Available from:

https://www.ncbi.nlm.nih.gov/pubmed/25467624

10. Nanditha A, Ramachandran A, Chamukuttan S, Chand JCC, Chia KS, Shaw, JE, Zimmet, P. Diabetes in Asia and the Pacific: implications for the global epidemic. Diabetes Care. 2016; 39:472-485. doi: $10.2337 / \mathrm{dc} 15-1536$

11. Chan JC, Cho NH, Tajima N, Shaw J. Diabetes in the western pacific region - past, present and future. Diabetes Res Clin Pract. 2014; 103(2):244-55. Available from:

https://www.ncbi.nlm.nih.gov/pubmed/24418400

12. Morell S, Lin S, Tukana I, Linhart C, Taylor R, Vatucawaqa P, et al. Diabetes incidence and projections from prevalence surveys in Fiji. Biomed Central. 2016; 14(45): 1-8. Available from: https:// biomedcentral.com/ articles/10.1186/ s12963-016-0114-0

13. Lin S, Tukana I, Linhart C, Morrel S, Taylor R, Vatucawaqa P, et al. Diabetes and obesity trends in Fiji over 30 years. J. Diabetes. 2016; 8(4):533-43. doi. 10.1111/1753-0407.12326

14. Institute for Health Metrics and Evaluation. Healthdata.org 2016 [cited 2017 Aug 11]; Available from: http://www.healthdata.org/fiji

15. Ministry of Health and Medical Services Fiji. Annual report 2015. Parliament of Fiji parliamentary paper no.79 of 2016. Suva Fiji: Ministry of Health and Medical Services; 2016

16. Brown AF, Ettner SL, Piette J, Weinberger M, Gregg E, Shapiro MF, et al. Socioeconomic position and health among persons with diabetes mellitus: a conceptual framework and review of the literature. Epidemiol Rev. 2004 [cited 2017 Apr 14]; 26: 63-77. Available from: https://www.ncbi.nlm.nih.gov/ pubmed/15234948

17. Walker RJ, Gebregziabher M, Martin-Harris B, Egede LE. Relationship between social determinants of health and processes and outcomes in adults with type 2 diabetes: validation of a conceptual framework. BioMed Central Endocrine Disorders. 2014 [cited 2017 Apr 14]; 14:82 Available from: https://bmcendocr disord.biomedcentral. com/articles/10.1186/1472-6823-14-82 
18. De Pablos-Velasco P, Parhofer KG, Bradley C, Eschwege E, Gonder-Frederick L, Maheux P, et al. Current level of glycaemic control and its associated factors in patients with type 2 diabetes across Europe: data from the PANORAMA study. Clinical Endocrinology. 2014; 80 (47): 56. Available from: http// www.medscape.com/viewarticle/817823

19. Abougalambou S, Suleiman A, Abougalambou A. Glycaeted haemoglobin control among type 2 diabetes patients attending a teaching hospital in Malaysia. Saudi Journal of Medical Pharmaceutical Science. 2015; 93 - 102. Available from: http://www.scholarsmepub.com/

20. Kellow N, Savige G, Khalil H. Predictors of poor glycaemic control during the initial five years postdiagnosis in rural adults with type 2 diabetes. Australian Journal of Rural Health. 2011; 19: 267 274. Available from: http//www. researchgate.net / profile/Nicole_Kellow/publication

21. UK Prospective Diabetes Study (UKPDS) Group: Tight blood pressure control and risk of macrovascular and microvascular complications in type 2 diabetes: UKPDS 38. BMJ. 1938; 317:703-713. doi: https://doi.org/10.1136/bmj.317.7160.703

22. Mahato RV, Gyawali P, RautPP, Regmi P, Singh KP, Pandeya DR, Gyawali P, et al. Association between glycaemic control and serum lipid profile in type 2 diabetic patients: glycated hemoglobin as a dual biomarker. Biomedical Research. 2011 ; 22 (3): 375 - 380. Available from:

https://www.researchgate.net/publication/215774283

23. Luijks H, Biermans M, Bor C, van Weel C, Lagro-Janssen T, de Grauw W, Schermer T. The effect of comorbidity on glycemic control and systolic blood pressure in type 2 diabetes: a cohort study with 5 year follow up in primary care. PLoS ONE. 2015; 10(10): e0138662.

doi:10.1371/journal.pone.0138662

24. Davis WA, Norman PE, Bruce DG, Davis TM. Predictors, consequences and costs of diabetes-related lower extremity amputation complicating type 2 diabetes: the Fremantle Diabetes Study. Diabetoloqia. 2006; 49 (11): 2534 - 41. Available from: https://www.ncbi.nlm.nih.gov/pubmed/ 17001469

25. Fiji Ministry of Health. Non-communicable Disease Steps Survey 2002. p. 32

26. Heisler M, Piette JD, Spencer M, Kieffer E, Vijan S. The relationship between knowledge of recent $\mathrm{HbA} 1 \mathrm{c}$ values and diabetes care understanding and self-management. Diabetes Care. 2005; 28(4):816-22. Available from: https://www.ncbi.nlm.nih.gov/pubmed/15793179

27. Nicholas J, Charlton J, Dregan A, Gulliford MC. Recent HbA1c values and mortality risk in Type 2 diabetes population-based case-control study. PLoS ONE. 2013; 8(7): e68008. Available from: https://doi.org/ 10.1371/journal.pone.0068008

28. Brian G, Ramke L, Maher L, Page A, Szetu J. The prevalence of diabetes among adults aged 40 years and over in Fiji. NZ Med J. 2010; 123 (1327): 68-75. Available from: https://www.nzma.org.nz/journal/read-the-journal/all-issues/2010-2019/2010/vol-123-no1327/article-brian

29. Kumar K, Snowdon W, Ram S, Khan S, Cornelius M, Tukana I, Reid S. Descriptive analysis of diabetes-related amputations at the Colonial War memorial Hospital, Fiji, 2010-2012. Public Health 
Action Journal. 2014; 4 (3): 155 - 158. Available from: http://www.ingentaconnect. com/ content/iuatld/pha/ 2014/ 00000004/00000003/art00008

30. Jyun-You Y., Chia-Fen M, Chao-Yu H. Medical appointment no shows associated with poor glycaemic control among Taiwanese aborigines. Australian Journal of Rural Health. 2012; 20 (6): 317 - 317. Available from: http://www.ncbi.nlm.nih.gov/medgen/633826

31. Abougalambou S, Suleiman A, Abougalambou A. Glycaeted haemoglobin control among type 2 diabetes patients attending a teaching hospital in Malaysia. Saudi Journal of Medical Pharmaceutical Science. 2015; 93 - 102. Available from: http://www.scholarsmepub.com/

32. Timothy G. Factors influencing glycaemic control in diabetics at three community health centres in Johannesburg. Diabetes Research Clinical Practice. 2010; 1-149. Available from: http://www.diabetesresearchclinical practice. com/article/S0168-8227(11)00097-0/pdf

33. Del Prato S, Felton AM, Munro N, Nesto R, Zimmet P, Zinman B. Improving glucose management: ten steps to get more patients with type 2 diabetes to glycaemic goal. Int J Clin Pract. 2005; 59(11):134555. doi: 10.1111/j.1742-1241.2005.00674.x

34. Kazmi NHS, Gillani S, Afzal S, Hussain S. Correlation between glycaeted haemoglobin levels and random blood sugar. J Ayub Med Coll Abbottabad. 2013; 25(1-2). Available from: http://www.ayubmed.edu.pk/ JAMC/25-1/Kazmi.pdf

35. Rasmussen JB, Nordin LS, Rasmussen NS, Thomsen JE, Street LA, Bygbjerg IC, Christensen DL. Random blood sugar may be used to assess long term glycaemic control among patients with type 2 diabetes mellitus in a rural African setting. Tropical Medicine and International Health. 2014; 19 (12):1515-1519. doi:10.1111/tmi.12391

36. Sacks DB. Correlation between hemoglobin A1c and average blood glucose concentration. J Diabetes Sci Technol. 2007; 1(6):801-3. Available from: http://journals.sagepub.com/doi/pdf/10.1177/193229680700100602

37. Rohlfing CL, Wiedmeyer HM, Little RR, England JD, Tennill A, Goldstein DE. Defining the relationship between plasma glucose and $\mathrm{HbA1c}$ : analysis of glucose profiles and $\mathrm{HbA} 1 \mathrm{c}$ in the diabetes control and complications trial. Diabetes Care. 2002; 25:275-78. Available from: https://www.ncbi.nlm. nih.gov/pubmed/11815495

38. Mahato RV, Gyawali P, RautPP, Regmi P, Singh KP, Pandeya DR, Gyawali P, et al. Association between glycaemic control and serum lipid profile in type 2 diabetic patients: glycated hemoglobin as a dual biomarker. Biomedical Research. 2011; 22 (3): 375 - 380. Available from: https://www.researchgate.net/publication/215774283

39. Borg R, Kuenen JC, Carstensen B, Zheng H, Nathan DM, et al. Associations between features of glucose exposure and A1C: the A1C derived average glucose (ADAG) study. Diabetes. 2010; 59:158590. doi: 2337/db09-1774

40. Rhee JJ, Ding VY, Rehkopf DH, Arce CM, Winkelmayer C. Correlates of poor glycemic control among patients with diabetes initiating hemodialysis for end-stage renal disease. BMC Nephrology. 2015; 16:204. Available from: https://doi.org/10.1186/s12882-015-0204-4 
41. Mooradian AD. Dyslipidemia in type 2 diabetes mellitus. Nat Clin Pract Endocr Metab. 2009; 5:150159. doi: 10.1038/ncpendmet1066.

42. Noor SK, Elmadhoun WM, Bushara SO, Almobarak AO, Salim RS, et al. Glycaemic control in Sudanese individuals with type 2 diabetes: population based study. Diabetes Metabolic Syndrome Journal. 2016; S1871-4021(16)30270-3. Available from: https://www.ncbi. nlm.nih.gov/pubmed/ 28034691

43. Sechi LA, Catena C, Zingaro L, Melis A, De Marchi S. Abnormalities of glucose metabolism in patients with early renal failure. Diabetes. 2002; 51:1226-32. Available from: https://www.ncbi.nlm.nih.gov/pubmed/11916949

44. Busch M, Nadal J, Schmid M, et al. Glycaemic control and antidiabetic therapy in patients with diabetes mellitus and chronic kidney disease - cross-sectional data from the German Chronic Kidney Disease (GCKD) cohort. BMC Nephrology. 2016; 17:59. Available from: https://www.ncbi.nlm.nih/gov/ pmc/ articles/PMC 4902996/

45. Hu H, Hori A, Nishiura C, Sasaki N, Okazaki H, Nakagawa T, et al. Hba1c, Blood pressure, and lipid control in people with diabetes: Japan epidemiology collaboration on occupational health study. PLoS One. 2016; 11(7): e0159071. doi: 1371/journal.pone.0159071

46. Gillespie EL, White CM, Kardas M, Lindberg M, Coleman Cl. The impact of ACE inhibitors or angiotensin II type 1 receptor blockers on the development of new-onset type 2 diabetes. Diabetes Care. 2005; 28:2261-6. pmid:16123505. Available from:

https://www.ncbi.nlm.nih.gov/pubmed/16123505

47. Liu F, Wu M, Feng Y, Zhong H, Cui T, Huang Y, et al. Influence of HbA1c on short-term blood pressure variability in type 2 diabetic patients with diabetic nephropathy. J Zhejiang Univ Sci B. 2013; 14(11): 1033-1040. doi: 1631/jzus.B1300030

48. UK Prospective Diabetes Study (UKPDS) Group: Tight blood pressure control and risk of macrovascular and microvascular complications in type 2 diabetes: UKPDS 38. BMJ. 1938; 317:703-713. doi: https://doi.org/10.1136/bmj.317.7160.703

\section{Tables}

Table 1. Clinical characteristics of T2DM patients attending clinics in three selected health centres in Suva, Fiji in 2011 - 2016 


\begin{tabular}{|c|c|c|c|}
\hline \multirow{2}{*}{$\begin{array}{c}\text { Variable } \\
(\mathrm{n}=338)\end{array}$} & \multicolumn{3}{|c|}{ Glycaemic Level } \\
\hline & $\begin{array}{c}\text { Good }(\mathrm{HbA} 1 \mathrm{C}<7 \%) \\
\mathrm{n}(\%)\end{array}$ & $\begin{array}{c}\text { Poor }(\mathrm{HbA} 1 \mathrm{C} \geq 7 \% \\
\mathrm{n}(\%)\end{array}$ & $\begin{array}{l}\text { Total } \\
\text { n (\%) }\end{array}$ \\
\hline \multicolumn{4}{|l|}{ Duration of Diabetes } \\
\hline$<5$ years & $48(14.2)$ & $160(14.3)$ & $208(61.5)$ \\
\hline $5-10$ years & $22(6.5)$ & $80(23.7)$ & $102(30.2)$ \\
\hline$>10$ years & $7(2.1)$ & $21(6.2)$ & $28(8.3)$ \\
\hline \multicolumn{4}{|l|}{${ }^{\mathrm{a} B M I}\left(\mathrm{~kg} / \mathrm{m}^{2}\right)$} \\
\hline Underweight (<18) & 0 & 0 & 0 \\
\hline Normal (18 - 24.9) & $12(3.5)$ & $50(14.8)$ & $62(18.3)$ \\
\hline Overweight (25 - 29.9) & $32(9.5)$ & $113(33.4)$ & $145(42.9)$ \\
\hline Obese $(>30)$ & $33(9.8)$ & $98(29.0)$ & 131 (38.8) \\
\hline \multicolumn{4}{|l|}{ bSBP $(\mathrm{mmHg}) \backslash$} \\
\hline Good control $(<130)$ & $28(8.3)$ & $108(32.0)$ & $136(40.2)$ \\
\hline Fair control (130-139) & $17(5.0)$ & $53(15.7)$ & $70(20.7)$ \\
\hline Poor control $(\geq 140)$ & $32(9.5)$ & $100(29.6)$ & $132(39.1)$ \\
\hline \multicolumn{4}{|l|}{ 'DBP (mmHg) } \\
\hline Good control $(<80)$ & $40(11.8)$ & $140(41.4)$ & $180(53.3)$ \\
\hline Fair control (80-89) & $22(6.5)$ & $89(26.3)$ & $111(32.8)$ \\
\hline Poor control $(\geq 90 \mathrm{mmHg})$ & $15(4.4)$ & $32(9.5)$ & 47 (13.9) \\
\hline \multicolumn{4}{|l|}{ d RBS (mmol/L) } \\
\hline Good control (4-8) & $35(10.4)$ & $25(7.4)$ & $60(17.8)$ \\
\hline Fair control (8.1-10) & $7(2.1)$ & $44(13.0)$ & $51(15.1)$ \\
\hline Poor control (>10) & $35(10.4)$ & $192(56.8)$ & $227(67.5)$ \\
\hline \multicolumn{4}{|l|}{${ }^{\mathrm{e}} \mathrm{FBS}(\mathrm{mmol} / \mathrm{L})$} \\
\hline Good control (4-6) & $37(11.0)$ & $38(11.2)$ & $75(22.2)$ \\
\hline Fair control (6.1-7) & $22(6.5)$ & $28(8.3)$ & $50(14.8)$ \\
\hline Poor control (>7) & $18(5.3)$ & $195(57.7)$ & $213(63.0)$ \\
\hline \multicolumn{4}{|l|}{ Cholesterol (mmol/L) } \\
\hline Good control $(\leq 4.0)$ & $24(7.1)$ & $52(15.4)$ & $76(22.5)$ \\
\hline Fair control (4.1-5.0) & $26(7.7)$ & $87(25.7)$ & $113(33.4)$ \\
\hline Poor control (>5.0) & $27(8.0)$ & $122(36.1)$ & $149(44.1)$ \\
\hline \multicolumn{4}{|l|}{ Triglyceride (mmol/L) } \\
\hline Good control $(<1.5)$ & $29(8.6)$ & $69(20.4)$ & $98(29.0)$ \\
\hline Fair control (1.5-2.0) & $29(8.6)$ & $106(31.4)$ & 135 (39.9) \\
\hline Poor control $(>2.0 \mathrm{mmol} / \mathrm{L})$ & $19(5.6)$ & $86(25.4)$ & $105(31.1)$ \\
\hline \multicolumn{4}{|l|}{$\mathrm{f}_{\mathrm{eGFR}}\left(\mathrm{ml} / \mathrm{min} / 1.73 \mathrm{~m}^{2}\right)$} \\
\hline Good control $(\geq 90)$ & $12(3.6)$ & $93(27.5)$ & 105 (31.1) \\
\hline Fair control $(60-<90)$ & $48(14.2)$ & $115(34.0)$ & $163(48.2)$ \\
\hline Poor control $(<60)$ & $17(5.0)$ & $53(15.7)$ & $70(20.7)$ \\
\hline \multicolumn{4}{|l|}{ Associated medical condition } \\
\hline No & $28(8.3)$ & $89(26.3)$ & $117(34.6)$ \\
\hline Yes & $49(14.7)$ & $172(50.9)$ & $221(65.4)$ \\
\hline
\end{tabular}

aMMI - Body Mass Index

${ }^{b}$ RBS - Random Blood Sugar

${ }^{c}$ FBS - Fasting Blood Sugar

${ }^{d}$ SBP - Systolic Blood Pressure

${ }^{\mathrm{e} D B P}$ - Diastolic Blood Pressure

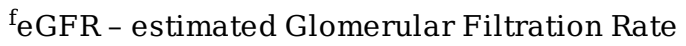

Table 2. Bivariate analysis of participant's clinical characteristics associated with glycaemic control 


\begin{tabular}{|c|c|c|c|}
\hline Clinical Characteristics & $\beta$ & Crude OR [95\% CI] & $p$ value \\
\hline $\begin{array}{l}\text { Duration of diabetes in years } \\
<5 \text { years } \\
5-10 \text { years } \\
>10 \text { years }\end{array}$ & $\begin{array}{c}0 \\
0.09 \\
-0.11\end{array}$ & $\begin{array}{c}1 \\
1.09[0.62,1.93] \\
0.90[0.36,2.25]\end{array}$ & $\begin{array}{l}.765 \\
.821\end{array}$ \\
\hline 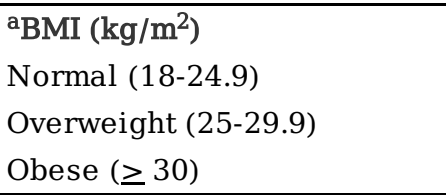 & $\begin{array}{c}0 \\
-0.17 \\
-0.34 \\
\end{array}$ & $\begin{array}{c}1 \\
0.85[0.40,1.78] \\
0.71[0.34,1.50]\end{array}$ & $\begin{array}{c}- \\
.662 \\
.372\end{array}$ \\
\hline $\begin{array}{l}\text { bSBP }(\mathrm{mmHg}) \\
\text { Good control }(<130) \\
\text { Fair control }(130-139) \\
\text { Poor control }(\geq 140) \\
\end{array}$ & \begin{tabular}{|c}
0 \\
-0.21 \\
-0.21 \\
\end{tabular} & $\begin{array}{c}1 \\
0.81[0.41,1.61] \\
0.81[0.46,1.44] \\
\end{array}$ & $\begin{array}{c}- \\
.543 \\
.473 \\
\end{array}$ \\
\hline $\begin{array}{l}\text { CDBP }(\mathrm{mmHg}) \\
\text { Good control }(<80) \\
\text { Fair control }(80-90) \\
\text { Poor control }(>90) \\
\end{array}$ & $\begin{array}{c}0 \\
0.15 \\
-0.50 \\
\end{array}$ & $\begin{array}{c}1 \\
1.16[0.64,2.07] \\
1.64[0.30,1.24] \\
\end{array}$ & $\begin{array}{c}- \\
.627 \\
.170 \\
\end{array}$ \\
\hline $\begin{array}{l}{ }^{\mathrm{d}} \mathrm{RBS}(\mathrm{mmol} / \mathrm{L}) \\
\text { Good control }(4-8) \\
\text { Fair control }(8.1-10) \\
\text { Poor control }(>10)\end{array}$ & $\begin{array}{c}0 \\
2.18 \\
2.04 \\
\end{array}$ & $\begin{array}{c}1 \\
8.80[3.41,22.72] \\
7.68[4.10,14.38]\end{array}$ & $\begin{array}{c}- \\
* .001 \\
{ }^{*} .001\end{array}$ \\
\hline 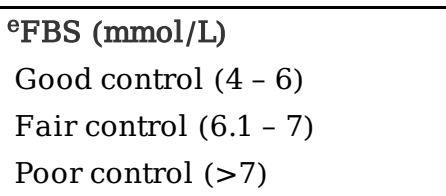 & $\begin{array}{c}0 \\
0.21 \\
2.36\end{array}$ & $\begin{array}{c}1 \\
1.24[0.60,2.54] \\
10.55[5.44,20.45]\end{array}$ & $\begin{array}{c}- \\
.559 \\
* .001\end{array}$ \\
\hline $\begin{array}{l}\text { Cholesterol }(\mathrm{mmol} / \mathrm{L}) \\
\text { Good control }(<4.0) \\
\text { Fair control }(4.0-5.0) \\
\text { Poor control }(>5.0)\end{array}$ & $\begin{array}{c}0 \\
0.44 \\
0.77\end{array}$ & $\begin{array}{c}1 \\
1.54[0.80,2.97] \\
2.09[1.10,3.95]\end{array}$ & $\begin{array}{c}- \\
.192 \\
* 024\end{array}$ \\
\hline $\begin{array}{l}\text { Triglyceride }(\mathrm{mmol} / \mathrm{L}) \\
\text { Good control }(<1.5) \\
\text { Fair control }(1.5-2.0) \\
\text { Poor control }(>2.0)\end{array}$ & $\begin{array}{c}0 \\
0.43 \\
0.64\end{array}$ & $\begin{array}{c}1 \\
1.54[0.85,2.79] \\
1.90[0.98,3.68]\end{array}$ & $\begin{array}{l}- \\
.159 \\
.056\end{array}$ \\
\hline $\begin{array}{l}\text { feGFR }(\mathrm{ml} / \mathrm{min} / 1.73 \mathrm{~m} 2) \\
\text { Good control }(>90) \\
\text { Fair control }(60-89) \\
\text { Poor control }(<60)\end{array}$ & $\begin{array}{c}0 \\
-1.17 \\
-0.91\end{array}$ & $\begin{array}{c}1 \\
0.31[0.16,0.62] \\
0.40[0.18,0.91]\end{array}$ & $\begin{array}{c}- \\
* .001 \\
* .028\end{array}$ \\
\hline $\begin{array}{l}\text { Associated medical condition } \\
\text { No } \\
\text { Yes }\end{array}$ & $\begin{array}{c}0 \\
0.10\end{array}$ & $\begin{array}{c}1 \\
1.10[0.65,1.88]\end{array}$ & $\begin{array}{c}- \\
0.714\end{array}$ \\
\hline
\end{tabular}

* Significant $\mathrm{p}<.05$.

${ }^{\mathrm{a} B M I}$ - Body Mass Index

${ }^{\mathrm{b}} \mathrm{RBS}$ - Random Blood Sugar

${ }^{\mathrm{c}} \mathrm{FBS}$ - Fasting Blood Sugar

${ }^{\mathrm{d}} \mathrm{SBP}$ - Systolic Blood Pressure

${ }^{\mathrm{e} D B P}$ - Diastolic Blood Pressure

feGFR - estimated Glomerular Filtration Rate

Table 3. Logistic regression of clinical characteristics on glycaemic Control. 


\begin{tabular}{|c|c|c|c|}
\hline Clinical Characteristics & $\beta$ & Adjusted OR [95\% CI] & $p$ value \\
\hline $\begin{array}{l}\text { Duration of diabetes in years } \\
<5 \text { years } \\
5-10 \text { years } \\
>10 \text { years }\end{array}$ & $\begin{array}{c}0 \\
0.32 \\
-0.36 \\
\end{array}$ & $\begin{array}{c}1 \\
1.37[0.64,2.97] \\
0.70[0.22,2.25]\end{array}$ & $\begin{array}{l}- \\
.421 \\
.546\end{array}$ \\
\hline 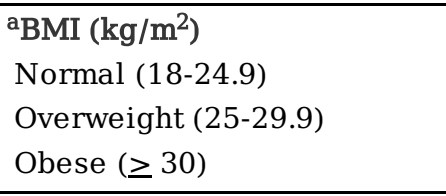 & $\begin{array}{c}0 \\
-0.51 \\
-0.46 \\
\end{array}$ & $\begin{array}{c}1 \\
0.60[0.22,1.66] \\
0.63[0.23,1.75] \\
\end{array}$ & $\begin{array}{c}- \\
.326 \\
.376 \\
\end{array}$ \\
\hline $\begin{array}{l}{ }^{\mathrm{b}} \mathrm{RBS}(\mathrm{mmol} / \mathrm{L}) \\
\text { Good control }(4-8) \\
\text { Fair control }(8.1-10) \\
\text { Poor control }(>10)\end{array}$ & $\begin{array}{c}0 \\
2.41 \\
2.07\end{array}$ & $\begin{array}{c}1 \\
11.11[3.45,35.73] \\
7.91[3.58,17.47] \\
\end{array}$ & $\begin{array}{c}- \\
{ }^{*} .001 \\
{ }^{*} .001 \\
\end{array}$ \\
\hline $\begin{array}{l}\text { CFBS (mmol/L) } \\
\text { Good control }(4-6) \\
\text { Fair control }(6.1-7) \\
\text { Poor control }(>7) \\
\end{array}$ & $\begin{array}{c}0 \\
0.31 \\
2.38\end{array}$ & $\begin{array}{c}1 \\
1.37[0.57,3.30] \\
10.75[4.85,23.81]\end{array}$ & $\begin{array}{c}- \\
.488 \\
* .001 \\
\end{array}$ \\
\hline $\begin{array}{l}{ }^{\mathrm{d} S B P}(\mathrm{mmHg}) \\
\text { Good control }(<130) \\
\text { Fair control }(130-39) \\
\text { Poor control }(\geq 140)\end{array}$ & $\begin{array}{c}0 \\
0.13 \\
0.08\end{array}$ & $\begin{array}{c}1 \\
1.14[0.47,2.80] \\
1.08[0.45,2.60]\end{array}$ & $\begin{array}{c}- \\
.769 \\
.858\end{array}$ \\
\hline $\begin{array}{l}{ }^{e} \mathrm{DBP}(\mathrm{mmHg}) \\
\text { Good control }(<80) \\
\text { Fair control }(80-90) \\
\text { Poor control }(>90) \\
\end{array}$ & $\begin{array}{c}0 \\
-0.04 \\
-1.17 \\
\end{array}$ & $\begin{array}{c}1 \\
0.96[0.43,2.14] \\
0.31[0.11,0.89] \\
\end{array}$ & $\begin{array}{c}- \\
.919 \\
* .030 \\
\end{array}$ \\
\hline $\begin{array}{l}\text { Cholesterol }(\mathrm{mmol} / \mathrm{L}) \\
\text { Good control }(<4.0) \\
\text { Fair control }(4.0-5.0) \\
\text { Poor control }(>5.0) \\
\end{array}$ & $\begin{array}{c}0 \\
0.76 \\
1.33 \\
\end{array}$ & $\begin{array}{c}1 \\
2.14[0.91,5.06] \\
3.77[1.60,8.90]\end{array}$ & $\begin{array}{c}- \\
.082 \\
* .002 \\
\end{array}$ \\
\hline $\begin{array}{l}\text { Triglyceride }(\mathrm{mmol} / \mathrm{L}) \\
\text { Good control }(<1.5) \\
\text { Fair control }(1.5-2.0) \\
\text { Poor control }(>2.0) \\
\end{array}$ & $\begin{array}{c}0 \\
0.37 \\
0.55 \\
\end{array}$ & $\begin{array}{c}1 \\
1.45[0.66,3.19] \\
1.74[0.74,4.04]\end{array}$ & $\begin{array}{c}- \\
.359 \\
.202\end{array}$ \\
\hline $\begin{array}{l}\mathrm{f}_{\mathrm{eGFR}\left(\mathrm{ml} / \mathrm{min} / 1.73 \mathrm{~m}^{2}\right)} \\
\text { Good control }(\geq 90) \\
\text { Fair control }(60-89) \\
\end{array}$ & $\begin{array}{c}0 \\
-1.65 \\
\end{array}$ & $\begin{array}{c}1 \\
0.19[0.08,0.48]\end{array}$ & $\begin{array}{c}- \\
* .001 \\
\end{array}$ \\
\hline Poor control $(<60)$ & -1.19 & $0.31[0.11,0.87]$ & ${ }^{*} .027$ \\
\hline $\begin{array}{l}\text { Associated medical condition } \\
\text { No } \\
\text { Yes }\end{array}$ & $\begin{array}{c}0 \\
0.19\end{array}$ & $\begin{array}{c}1 \\
0.82[0.22,3.16]\end{array}$ & $\begin{array}{c}- \\
.777\end{array}$ \\
\hline
\end{tabular}

* Significant $p<.05$

aMI - Body Mass Index

${ }^{b}$ RBS - Random Blood Sugar

${ }^{\mathrm{c}} \mathrm{FBS}$ - Fasting Blood Sugar

dSBP - Systolic Blood Pressure

eDBP - Diastolic Blood Pressure

feGFR - estimated Glomerular Filtration Rate

Table 4. Final model of factors significantly associated with glycaemic control among T2DM patients attending clinics at Suva Health Centres, Fiji in 2011 - 2016 


\begin{tabular}{|c|c|c|c|}
\hline Independent variables & $\beta$ & Adjusted OR [95\% CI] & $p$ value \\
\hline${ }^{a} \mathrm{RBS}(\mathrm{mmol} / \mathrm{L})$ & & & \\
\hline Good control $(4-8)$ & 0 & 1 & - \\
\hline Fair control $(8.1-10)$ & 2.28 & $9.76[3.11,3.60]$ & ${ }^{*} .001$ \\
\hline Poor control (>10) & 1.96 & $7.13[3.31,15.35]$ & ${ }^{*} .001$ \\
\hline${ }^{b}$ FBS (mmol/L) & & & \\
\hline Good control $(4-6)$ & 0 & 1 & \\
\hline Fair control $(6.1-7)$ & 0.19 & $1.21[0.52,2.82]$ & .659 \\
\hline Poor control (>7) & 2.33 & $10.28[4.74,22.31]$ & ${ }^{*} .001$ \\
\hline Cholesterol (mmol/L) & & & \\
\hline Good control $(<4.0)$ & 0 & 1 & 1 \\
\hline Fair control $(4.0-5.0)$ & 0.76 & $2.14[0.92,4.99]$ & .078 \\
\hline Poor control $(>5.0)$ & 1.38 & $3.98[1.70,9.17]$ & ${ }^{*} .001$ \\
\hline${ }^{\mathrm{c} e G F R}\left(\mathrm{ml} / \mathrm{min} / 1.73 \mathrm{~m}^{2}\right)$ & & & \\
\hline Good control (> 90) & 0 & 1 & \\
\hline Fair control $(60-89)$ & -1.60 & $0.20[0.09,0.48]$ & ${ }^{*} .001$ \\
\hline Poor control $(<60)$ & -1.11 & $0.33[0.12,0.91]$ & ${ }^{*} .032$ \\
\hline${ }^{\mathrm{d} D B P}$ & & & \\
\hline Good control $(<80)$ & 0 & 1 & - \\
\hline Fair control $(80-90)$ & 0.01 & $1.01[0.48,2.13]$ & .973 \\
\hline Poor control (>90) & -1.13 & $0.32[0.13,0.82]$ & $* .017$ \\
\hline
\end{tabular}

* Significant $p<.05$

${ }^{\mathrm{a}} \mathrm{RBS}$ - Random Blood Sugar

${ }^{b}$ FBS - Fasting Blood Sugar

ceGFR- estimated Glomerular Filtration Rate

${ }^{d}$ DBP - Diastolic Blood Pressure

Figures 
Total records of T2DM patients registered on

August 1, 2011 - August 1, 2016

( $N=\mathbf{2 , 0 7 3 )}$

- Suva Diabetes Centre $=563$

- Valelevu Health Centre $=992$

- Lami Health Centre $=518$

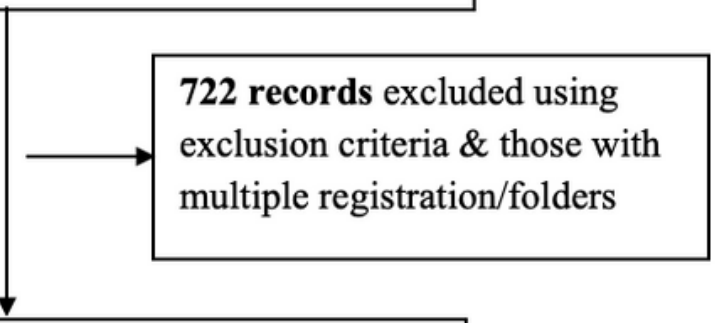

Total unique records included based on

inclusion criteria $(\mathbf{N}=\mathbf{1 , 3 5 1})$

- Suva Diabetes Centre $=478$

- Valelevu Health Centre $=694$

- $\quad$ Lami Health Centre $=179$

Total eligible samples using proportional sampling method adjusted by a factor of $10 \%$ for incomplete records $(n=354)$

- Suva Diabetes Centre $=132$

- Valelevu Health Centre $=172$

- Lami Health Centre $=50$

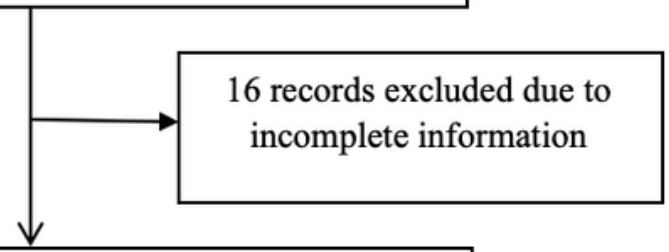

Total samples included in data collection and

$$
\text { analysis }(n=338)
$$

- Suva Diabetes Centre $=132$

- Valelevu Health Centre $=156$

- Lami Health Centre $=50$

Figure 1

Patient selection flow chart 